\title{
Implementation of Place-Based Education: A Case Study in a Primary School at Talhogang, Bhutan
}

\author{
Kuenzang Dorji ${ }^{1}$, Kinley $^{2}$, Alexander Sivitskis ${ }^{3}$ \\ ${ }^{1}$ Tsangkha Middle Secondary School, Dagana, Bhutan \\ ${ }^{2}$ Department of Science Education, Samtse College of Education, Royal University of Bhutan, Samtse, Bhutan \\ ${ }^{3}$ Department of Social Science Education, Samtse College of Education, Royal University of Bhutan, Samtse, Bhutan \\ Email: kuenzangd@education.gov.bt
}

How to cite this paper: Dorji, K., Kinley, \& Sivitskis, A. (2021). Implementation of Place-Based Education: A Case Study in a Primary School at Talhogang, Bhutan. Creative Education, 12, 2390-2409. https://doi.org/10.4236/ce.2021.1210180

Received: August 13, 2021

Accepted: October 23, 2021

Published: October 26, 2021

Copyright ( 2021 by author(s) and Scientific Research Publishing Inc. This work is licensed under the Creative Commons Attribution International License (CC BY 4.0).

http://creativecommons.org/licenses/by/4.0/ (c) (i) Open Access

\begin{abstract}
This research titled "implementation of place-based education: a case study in a primary school at Talhogang" was conducted with an aim to explore how place-based education (PBE) was implemented in an innovative Bhutanese place-based pilot school. The objectives of the study were to investigate the potential influence of place-based education on students' engagement in learning and further describe the place-based education assessment practices carried out in the school. In addition to identifying the opportunities and challenges teachers face in implementing place-based education, the study also explored the relationship between PBE and Gross National Happiness (GNH), the guiding developmental philosophy of Bhutan. This qualitative study with an exploratory case study by design grounded its foundation on the constructivist worldview. Purposive sampling was used to solicit data from respondents who had experienced the phenomenon under study. The sample consisted of six teachers and eight students. Semi-structured interview, classroom observation and document analysis were employed to gather data from the participants. After the thematic and content analysis, data from these different sources were triangulated to authenticate the validity of the findings. The findings of the study revealed that the local community was used as an extended part of a classroom enabling students to gain hands-on learning experiences. In addition, analysis of the data indicates that the PBE School employed a variety of authentic assessment practices to evaluate the progress of learning. The study also demonstrated that there is a strong synergy between $\mathrm{PBE}$ and GNH, particularly intellectual and academic dimensions within the concept of Green School. While the results indicated that the PBE was implemented successfully, several barriers were likewise identified. Accordingly,
\end{abstract}


recommendations to address these challenges of implementation are offered this educational approach more effectively.

\section{Keywords}

Place-Based Education, Experiential Learning, Green School, Educating for Gross National Happiness

\section{Introduction}

The Royal Government of Bhutan accords maximum priority to the education sector as the country's quality of health, prosperity, contentment and advancement hinges on the quality of its education. Towards this end, the Bhutanese Ministry of Education has taken numerous reform initiatives to pursue improvements in access, equity and system efficiencies in order to improve the quality of education in the country.

Beginning in the 1960's with limited local capacity, first efforts to modernize Bhutan's educational system were largely reliant on resources and teaching staff from India (Denman \& Namgyel, 2008; Gyamtso et al., 2017). As a result of this foreign dependence, teacher-centered approaches characteristic of the AngloIndian school systems steadily became the norm in Bhutanese classrooms (Gyamtso et al., 2017; Gyamtso \& Maxwell, 2012). While enabling progress in the way of modernizing education, this reliance on outside curriculum was soon recognized as problematic for the achievement of long-term and sustainable educational reform.

Seeking to improve the state of educational development, a trend towards the Bhutanisation of curriculum was initiated in the mid 1980's (Gyamtso, 2013). This trajectory focused on the incorporation of traditional values and subject matters in order to align Bhutan's teaching and learning practices with national needs and aspirations (Education Division, 1989). Incorporation and assimilation of more modern approaches including student-centered instruction, inquiry and hands-on learning, an increased emphasis on authentic learning processes and focus on more relevant content serve as a testament to this transitional period (Dolkar, 1995; Phuntsho, 2000).

To further expedite quality learning for a $21^{\text {st }}$-century education, major initiatives have been introduced in the education system in recent years. The Bhutanese Ministry of Education (MoE) initiated an effort to update teaching methods and allow teachers to better engage students by training them on transformative pedagogy (Wangdi, 2016) and English for Effective Communication (Rinzin, 2017). Bhutan's iSherig-1 and then subsequently the iSherig-2 Education ICT master plan 2019-2023 was developed to gear the power of ICT as an enabling tool in teaching and learning as well as to rationalize and streamline ICT activities, systems and projects across the education sector (MoE, 2019). The Bhutan Education Blueprint 2014-2024 was launched in 2015 to provide a time-bound 
strategic roadmap for a systematic transformation of the school education system in Bhutan (The Bhutanese, 2015). More recently, Bhutan Professional Standard for Teachers (BPST), a framework for development of teachers was launched to serve as a new standard to measure teachers' competencies (Zangmo, 2019). The Bhutanese Royal Education Council (REC) has introduced major reforms in curriculum and pedagogical practices. The curriculum was rationalized to provide time for the active engagement of students in learning by translating the learnt concepts into practical skills in a real-life environment (Wangchuk, 2019).

Despite the history of reform efforts, the Bhutanese education system still faces setbacks in delivering quality education (Bhutan Council for School Examinations and Assessment [BCSEA], 2019). Balancing the goals of "modernization" alongside the "Bhutanisation" of the country's educational system has remained a consistent challenge in this developmental progression. Phuntsho (2000) pointedly articulates how the secular modern educational movement is often viewed in dissonance with traditional educational approaches steeped in the unique cultural and rich values-oriented Buddhist heritage of Bhutan.

Finding ways to bridge the gap between these two unique goals in the face of progress has therefore become of utmost importance. Identifying innovative approaches that can equally balance the educational challenges of Bhutan remains a pursuit throughout the educational system. While many approaches have been proposed to address this need, one promising innovation for the nation is the introduction of Place Based Education.

Beginning 2008, the Government of Bhutan ventured into a partnership with the USA-based educational non-profit Teton Science Schools in an effort to introduce and expand place-based education in the country. Teton Science Schools (TSS), located in Wyoming USA, is a recognized as a dynamic advocate for place-based education. As an organization, TSS offers multiple formal and informal educational experiences under a common mission of inspiring curiosity, engagement and leadership through transformative place-based education. To achieve this mission, TSS focuses on developing three framework competencies: educational approach, intentional culture, and community leadership. For each of these competencies, the approach is place-based, connecting classrooms and communities through the progression of self, community, and the world (Teton Science Schools [TSS], 2017).

Over the last decade, the collaboration between TSS and Bhutan has strengthened, building momentum for place-based education (PBE) through supporting teachers, administrators, and institutions. Primary efforts have been focused on conducting place-based workshops and professional development programmes across multiple educational organizations. The ideas of PBE were also introduced to pre-service teachers in two teacher training colleges in the nation after the college faculty was trained in PBE. Partnerships with individual institutions have proven central to the mission of PBE implantation. These evolving relationships provided flexibility for implementation, enabling customized and tar- 
geted educational support.

One emerging leader in Bhutan's journey of PBE is the non-profit organization the Youth Development Fund (YDF). As a broad-reaching organization, YDF coordinates multiple initiatives across Bhutan focused on improving educational equity, opportunity, and access for the nation's youth. One of YDF's flagship programmes is an educational initiative known as the My Gakidh Village School (MGVS). A collaborative project between Bhutan's MoE and YDF, this school is intended to serve as the pilot PBE School in the nation. This study sought to investigate the implementation of PBE at the MGVS, and ascertain how this innovative educational approach has influenced teaching and learning practice, assessment, and outcomes.

\section{Literature Review}

\subsection{Place-Based Education}

Semken and Freeman (2008) define place-based education as "an instructional method that involves experiential learning in and about local or regionally characteristic natural and social settings; transdisciplinary and cross-cultural synthesis of place-related knowledge and pedagogy; and service-learning or other forms of community outreach" (p.1043). While others describe it as an instructional approach that allows teachers to use local resources to engage students in learning through real-world experience (Nespor, 2008; Resor, 2010). Furthermore, a place-based educational approach is one that is related to Environmental Education (EE), which places emphasis and priority towards education for sustainability (Barnett, 2009; Shannon, 2017). Ultimately, place-based education is an inter-disciplinary and experiential learning approach which engages the local environment and society as context for learning.

As an innovative approach to education, PBE can materialize across many disciplines and instances. To provide a common structure for implementing and discussing place-based learning, Teton Science Schools (TSS) worked to synthesize a set of six learning principles which appear foundational to PBE. These principles emerged in collaboration with Annenberg Rural Challenge in the 1990s, as well as a product of a joint Teton Science Schools. University of Wyoming partnership in the 2000s (Vander Ark et al., 2020). Figure 1 displays a graphic rendering of the PBE principles.

According to Kinley and Griffin (2017), these principles "guide the various programs offered at TSS and provide a structure for implementing PBE to a wide array of places" (p. 6). Two key models that help situate a place-based learning experience are the local to global and learner-centered approaches. Starting with "local to global context," authentic PBE applications strive to engage local learning opportunities to model how one understands prospects, connections and challenges on a local level before applying the ideas to a larger world. Likewise, this context allows both educators and students to consider how global issues and opportunities are reflected within their own local environments. Learner-centered 

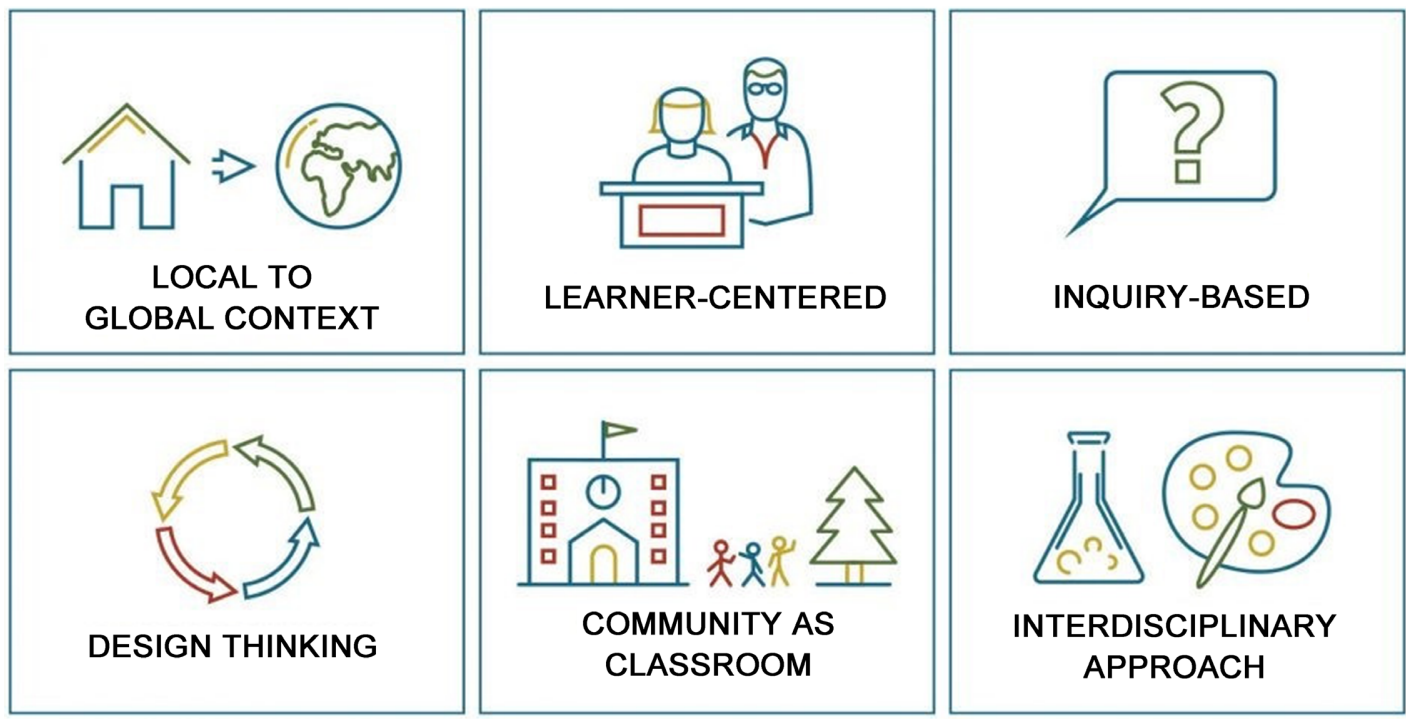

Figure 1. Six place-based education principles as shared by TSS.

approach is personally pertinent to students and celebrates the development of student agency. In this form of student-centered learning, students get the opportunity to collaboratively guide their learning experience through their instructor's direct incorporation of student voice of interest and choice. Thus, the experience of students is more about learning and less about teaching (TSS, 2019).

Though still developing in the body of literature, the impacts of PBE are consistently found to be wide-reaching. As an approach that connects learning to communities, PBE has been demonstrated to increase engagement, outcomes (academic and social-emotional), and community impact (Smith, 2017; Thapa et al., 2013). In the long-term, place-based approaches can also increase student agency, community, and equity in that all students see themselves with the necessary skills and resources to be a part of a thriving community (Vander Ark et al., 2020). Through active learner-centered inquiry using the surrounding community as a classroom, students to explore relevant local phenomena as a means to contextualize a broader global understanding (Smith, 2017; Sobel, 2004). PBE, therefore affects positive changes in students' learning outcomes as compared to the traditional methods of teaching. For these reasons, PBE has been hypothesized to be one innovative approach that can actualize Bhutan's planned vision of Educating for Gross National Happiness (EdGNH).

\subsection{Educating for Gross National Happiness (EdGNH) and Green Schools}

First articulated by the Fourth King Jigme Singye Wangchuk in 1972 (Planning Comission, 1999; Sherab, 2013), his majesty historically declared for Bhutan that "Gross National Happiness is more important than Gross National Product." Through this declaration, the King subsequently set Bhutan's developmental trajectory towards maximizing the happiness of the country's population. GNH 
seeks to reimagine the concept of national development in light of limitations of traditional metrics (i.e. Gross Domestic Product (GDP)). Aiming to follow a so called "middle path," a country guided by GNH strives to balance economic development alongside environmental and cultural preservation through the practice of good governance (Wangmo \& Valk, 2012).

The foundations of GNH are grounded within the wisdom of Buddhist teachings, namely that individuals can gain merit through moral actions aimed to support all sentient beings of the collective world (Gyamtso et al., 2017; Sherab, 2013). These moral actions (stemming from intellectual values) are categorized around central developmental objectives (pillars) that support the economy, culture, environment, and governmental proceedings of the nation. Ultimately, in order for development guided by GNH to occur, it is thought that all Bhutanese must practice and embody actions to uphold these pillars.

Education is the GNH domain that receives the most attention in Bhutan. In 2009, the Bhutan Ministry of Education begun a nation-wide change initiative called Educating for Gross National Happiness (Hayward \& Colman, 2010). Educating for GNH according to Ministry of Education (2012) "cites ways and means with which GNH values can be ingrained in schools, pillar-wise" (p. 3). Concurrently, the Green School initiative emerged from the EdGNH movement as a structure to actualize these GNH concepts.

Green School is an educational idea that Bhutan embraced about ten years ago to transform the nation's schools into positive, evergreen places of learning for students. While the concept of a green school exists around the world, the idea in Bhutan is used figuratively for the eight different dimensions prerequisite for the wholesome development of each child in school (MoE, 2012).

The Green School concept has been implemented in the Bhutanese school system under a structure of eight dimensions. According to Powdyel (2014), who is one of the important promoters of Green School for Green Bhutan, these are dimensions are Natural Greenery, Intellectual Greenery, Academic Greenery, Social Greenery, Cultural Greenery, Spiritual Greenery, Aesthetic Greenery, and Moral Greenery. Powdyel (2014) further asserts that the practice of these green dimensions can engage and empower "all the elements of the learner." Such an approach strives towards the goal of developing graduates capable of bringing positive impact across local and global communities alike. Supporting this vision, the Ministry of Education (2013) further shares that a "green school is a holistic approach to promote values and principles of Gross National Happiness in the school system and nurture students who are infused with the GNH values and principles" (p. 121).

Though the Ministry of Education has provided some guidance for educators to incorporate GNH into their practice, challenges to enact this harmonious vision persist for the Bhutanese educational community. Powdyel (2014) asserts that though "some good materials have been developed to help implement the elements of a green school, there is a pressing need for resources which support 
educators and students to obtain a more profound understanding of the concepts themselves" (p. 5). Finding an educational approach to meet this need remains utmost priority for educators in Bhutan

By centering education around this multidimensional concept of place, it is believed place-based pedagogy can offer a concrete approach that for Bhutanese educators to engage their students with the principles and values of Educating for GNH and explore the dimensions of the Green School concept. Accordingly, this paper sought to investigate how the implementation of place-based education (PBE) is emerging as one method to adequately address these challenges. While all the eight dimensions of Green Schools are significant Bhutanese Education in fulfilling the objectives of Educating for GNH two dimensions (namely academic and intellectual greenery) surfaced significantly in this study. Therefore, the possibility of enhancing academic and intellectual greenery with the implementation of PBE in a Bhutanese classroom were closely examined.

\section{Methods and Methodology}

The study adopted a qualitative approach. Qualitative research is a means for exploring and understanding the meaning of individuals or groups credited to a social or human problem. The process of research involves data typically gathered in the participant's setting, data analysis inductively constructing from particulars to general themes, and the researcher making interpretations of the sense of the data (Creswell, 2009; Creswell, 2014). The intention of adopting this particular approach was to explore and understand the phenomenon within a given context because little research has been done on it.

A purposive sampling was used to select participants for this study in order to gain deep insights and experiences of teachers practicing PBE. The focus was on this particular group of participants as they had experiences of aligning the professional practices with the philosophy and pedagogies of PBE, particularly with engaging community resources and authentic project-based learning. Furthermore, Creswell and Poth (2016) mention that such kind of sampling will intentionally sample a group of people that can best inform the researcher about the research problem under examination. A total of 14 participants comprising of six teachers and eight students of the school took part in this endeavor.

Observations, semi structured interviews, and document analysis methods were used to garner data for this study. The data was gathered by actually talking directly to people and seeing them behave and act within their context. Multiple forms of information were gathered rather than relying on a single data source. The researchers maintained a focus on making sense of the participants' meanings, not the researchers' own meaning or the meanings that writers have expressed in the literature.

Face-to-face interviews were conducted with teachers of the school to elicit their views and experiences of implementing PBE and to obtain detailed perspectives on the subject. Semi-structured interviews were also carried out with 
students by framing different questions for their level. The semi structured interview approach provided opportunities for flexibility in interview administration, targeting often challenging conditions of interviewing respondents. This adaptable format reduced strict adherence from a planned questions and enabled changing the wording of questions when appropriate (Opie, 2004).

Classroom observation was done to pursue and unveil the phenomena in practice (Gillis \& Jackson, 2002). For this study, nonparticipant or observer as a participant was considered an appropriate approach to implement for this activity. The researchers played the role of the observer as a participant, watching and taking field notes from a distance.

Document analysis was completed as a final approach to data collection. Some documentary examples include personal documents are e-mails, scrapbooks, blogs, Facebook post, reflections and journals. Public documents in this study included curriculum framework, lesson plans, teacher's manual books, textbooks, and students' notebooks and portfolios. Documentary analysis served as a valuable compliment to data gathered through interviews and observations. As the essence of documents cannot be changed by the influence of researchers or research process, this data served non-reactive and stable source of information (Bowen, 2009).

An inductive approach was followed to generate codes directly from the data. The responses from the interview were transcribed since the original data source was an audio recording. The observation field notes were expanded into a word processing file. The data analysis process began by segmenting which involved dividing the data into meaningful analytical units. It was followed by coding; marking the segments of data with symbols, descriptive words or category names. The codes were then analysed for suggestive themes. Themes with similar meanings were merged together to represent a whole set of idea. Finally, the data were winnowed, narrowing down to a small manageable set of themes to write into a final narrative.

Triangulation of multiple data sources was used to strengthen the validity of this study. Different data sources were examined to build a coherent justification for themes by corroborating evidence from different sources to enlighten on a theme (Creswell, 2009). Member checking was employed to determine accuracy of qualitative findings with participant reviews of thematic analysis. Follow-up interviews were also conducted with participants to ensure the accuracy of their perspectives and statements. Following suggestions from Gibbs (2007), additional procedures were used to evaluate the reliability of findings. Reviews of transcripts and codes were conducted by the research team, and inter-coder reliability was assessed to compare agreement between coded qualitative data.

There are few limitations that have to be considered in this study. The sampling was restricted to a particular site and hence, the findings from the study do not represent the views of teachers across the nation that implement PBE. Therefore, it is beyond the framework of this research to generalize on how PBE 
is being implemented in other schools across the country. Additionally, the small sample size of this study also limits the generalizability of the findings. However, this case study approach provides an in-depth examination of the place-based phenomenon at a function pilot school, and therefore serves as an authentic representation of place-based educational practice in Bhutan.

\section{Results and Discussion}

\subsection{Community as a Classroom}

The study demonstrated that teachers frequently use the local community as a classroom. The learning at the MGVS often took place beyond the four walls of the traditional classroom and the local community became the context for many learning experiences. The use of the local community for learning was evident during the several rounds of observations made in the school.

In one of the English classes of grade III, the topic of the lesson was on "emotion". After the discussion on emotional words in the class, students were led out in the woods a few meters away from the school by the teacher to make some observations (Figure 2(a)). While in the process of practicing observations in nature, they were provided with a task to describe how they feel when they see something. At the end of the lesson, children journaled down how they felt while making observations in nature.

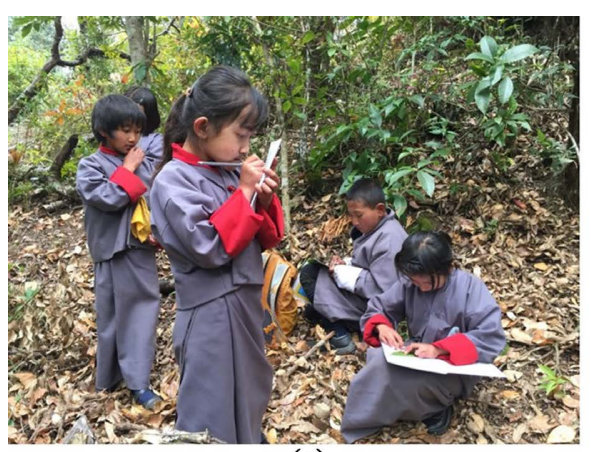

(a)

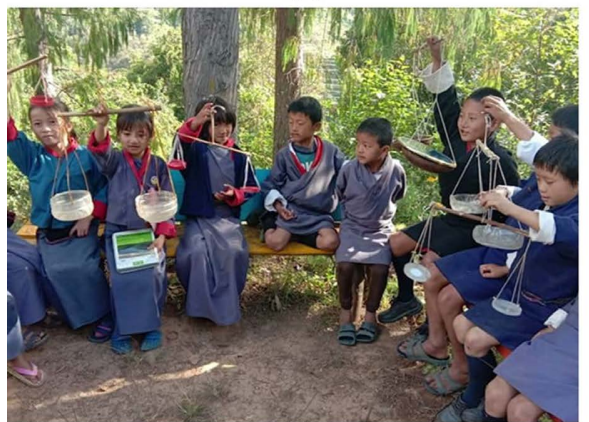

(b)

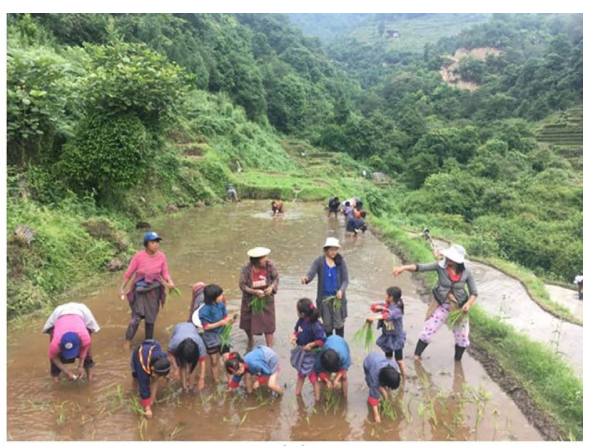

(c)

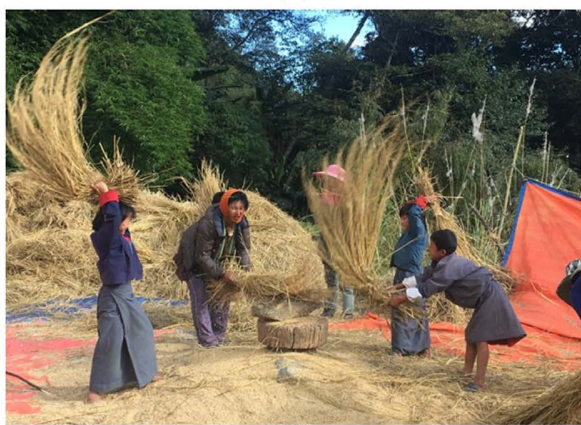

(d)

Figure 2. Example of students at the MGVS engaging with the local community as a classroom: (a) students explore the concept of emotions in the woods near campus; (b) students investigating mathematical concepts of mass using traditional measuring techniques; (c) students working with local community members for summer rice paddy cultivation; and (d) students processing harvested rice using traditional methods. 
In another mathematics lesson of grade II on the topic "Mass", students made a short trip to a nearby shop in the community as a follow-up activity of the concept. The objective of the visit was to check the mass of the items sold in the shop. Children were able to identify measurement terms such as "gram" and "kilogram" mentioned on each material sold in the shop. Extended lessons featured students creating their own traditional measuring scales, and compare metric units to traditional measurement systems (Figure 2(b)).

Document analysis further revealed that the school is involved in community projects such as mass cleaning, paddy plantation and local festivals as an extended part of classroom learning. For instance, in a paddy plantation project, elderly people in the village guide students on the processes such as plantation, harvesting and winnowing (Figure 2(c), Figure 2(d)). Over the course of this multi-month project, students returned to the same village locations to actively learn about and engage in the traditional systems of rice cultivation.

These activities were guided by the PBE principle community as a classroom and local to global in which Teton Science Schools (n.d.) states that communities serve as a learning environment where local people, experiences and places become a part of the extended meaning of a classroom. The idea echoes the proposition of Powdyel (2014) who in his book My Green School asserts that "if we have learnt to build harmony and goodwill at school, we will be the instruments of harmony and goodwill wherever we go after school and each one of us will carry these life-saving graces to our home, our society, our nation, and the world beyond" (p. 20).

According to Powers (2004), education grounded in the local community helps students see the relevance of what they are learning, which, in turn, increases their engagement in the learning process. Learning becomes meaningful as the learner is engaged in issues related to both human and environmental systems that directly affect them and other members of their community. When place-based education links students to their local community and environment while connecting the chain to the teaching of science, mathematics, social studies, writing, reading, and other subjects across the curriculum, it helps students learn to care for the world by understanding where they live (Smith, 2002; Woodhouse \& Knapp, 2000).

Schools involved in place-based education believe that it intentionally influences awareness of teachers and students and encourages local ecological and cultural ownership, rather than the global spirit of competitiveness and resource misuse (Semken, 2005). This intentional approach to learning increases awareness of diverse viewpoints as a facet of a democratic society, advances critical-thinking skills leading to discovery and real-world problem-solving, and a helps to build a comprehensive understanding of the world (Sobel, 2004). Ultimately, by engaging community as a classroom, educators and students alike are able to forge individual connections to something that is individually meaningful and fulfilling (Sobel, 2004; Semken \& Brandt, 2010).

Evidence from community-based learning at the MGVS supports previous work as indicated by research completed in other international contexts. Dani (2019) 
in a study a community and place-based approach to middle childhood science teacher education, found that community-based learning enrich student experiences. This theme also echoes similar findings by Bartholomaeus (2006) and Akbas \& Cakmak (2019).

A possible explanation for the observed success of this community-based learning practice at MGVS can be interpreted with analysis of teachers' response to the interview questions. Respondents frequently described how continuous professional development from an educational consultant with a background in PBE enabled their success in community-based teaching. MGVS, as a PBE pilot school collaboration between the non-profit organization the Youth Development Fund (YDF) and the Bhutanese government, is able to support the on-site placement of this resident PBE consultant. This consultant, working in partnership with Teton Science Schools (TSS), is able to provide in-person PBE training and support for local teachers for roughly 5 months of the academic year. Interview responses describe how collaboration between this resident consultant and the local teachers facilitated the educational engagement of location surrounded with rich environmental biodiversity of cultural heritage. Such responses demonstrate the positive potential for collaboration between these educational and nonprofit organizations invested into this pilot project.

\subsection{Hands on Learning Experience}

Observations and document analyses from the MGVS indicate that the principles of PBE were found to deeply immerse students in experiential learning. The information established from the qualitative data of teachers showed that in a PBE class the focus of teaching shifts from teacher-centred to student-centred approach. This claim was echoed by students' who revealed that they have the ownership of learning. Moreover, students were observed to participate in handson learning experience while shouldering the role of a non-participant observer during the school instructional hours. In one of the mathematics lessons of grade II, on the topic "capacity", students were engrossed in measuring the capacity of some local materials available in the school. It was a group activity to measure the capacity of things with water. The teacher acted as a guide and the focus of the PBE principle was learner-centred.

Similarly, in an English lesson of grade II on the topic "what I see", students were led out in nature to describe what they could visually observe around the school campus. The PBE principles driving this lesson were the learner-centred approach and the community as a classroom model. Students were provided with a hand lens to make better observations and at the end of the lesson, they had to present their findings. The students also made a short field trip to a nearby stream for bird watching and identifying organisms in the water. During the field trip, children identified different birds, insects and plants available in the locality referring to a guide book. They discussed the features of the local vegetation. The trip to a stream was an engaging, stimulating and educative experience 
for children.

PBE leverages active learner-centered inquiry by using a student's community as their classroom. By situating learning in relevant local phenomena and people, the place-based approach then facilitates students to contextualize their learning with a broader global understanding (Smith, 2017; Sobel, 2004). Therefore, PBE principles create an ambience of learning where "the life of a seat of learning ought to be consciously organized to achieve the most creative engagement of the scholar's mind" (Powdyel, 2014: p. 29). This context may lead to cultivation of minds that engage in "positive thinking, constructive dialogue, and meaningful action that make a welcome difference to the way things are" (p. 29). Thus, "the quality of minds that we nurture in our seats of learning decides the intellectual life of the nation" (Powdyel, 2014: p. 30). In this way, a PBE approach can directly promote the intellectual greenery in schools.

It is also evident that the academic greenery of green school would be enhanced with place-based education. When children are meaningfully engaged in a PBE class, learning becomes "fun and living". When the lessons are driven by PBE principles such as learner-centred, inquiry base and design thinking, every field is explored through "experiments and explorations, trails and investigations, reflections and presentations" (p. 34). Hence, PBE would enable Bhutanese students to take pride in excellence-speaking well, reading well, writing well, listening critically, thinking intelligently, analysing critically and interpreting objectively (Powdyel, 2014).

This finding aligns with previous studies which indicated similar experiences achieved by students in a PBE class. For example, place-based activities served as a means to experience learning beyond the classroom and often added a social dimension, fostering deep interactions, thus building engagement (Goodlad \& Leonard, 2018). The study also indicated that students were more active and engaged in their learning with PBE approaches compared to traditional classroom approaches. Similarly, Koinis (2016) found out approaches such as the 5-E model, project-based lessons, and field trips were implemented in order to stimulate hands-on learning experience for children. Tinder (2018) studied the impacts of place-based education in a middle secondary science classroom and reported that students had a much easier time understanding the active and dynamic process of geology by studying it in the field through observations and interpretations of results with hands-on learning experience. Likewise, middle school student responses indicated that they enjoyed learning environmental science concepts in a hands-on, active, and experiential way in another study by James and Williams (2017). A research conducted by Miller and Twum (2017) demonstrated PBE principles promoted effective teaching and hands on learning experiences when students took charge of their own learning.

\subsection{Opportunities and Challenges}

In pursuance of the opportunities and challenges in implementing place-based 
education in a Bhutanese classroom, the present study showed that along with the opportunities, there are several obstacles that hinders the effective implementation of PBE. Some of the opportunities that make possible and convenient for PBE suggested by the study were small size of students, location of the school in a bio diverse region, rich local culture and tradition and affiliation of the school to the YDF's My Gakidh Village project. On the other hand, teachers also expressed various obstacles they encounter while executing this educational approach in our context. The most prominent concerns shared by the participants were the lack of professional development programs and the time constraint. The other issues teachers constantly face were the language barrier, lack of resources, location of the school being away from the motor road, lack of knowledge about the local culture and tradition, least knowledge on PBE, minimum experience of applying in lessons, and weather conditions.

This finding is in line with Miller and Twum (2017) and Powers (2004) where respondents outlined the need for knowledge and skills required to design and implement PBE in practice more successfully. The study also indicated teachers to become competent in approaches such as inquiry-based, integrated and interdisciplinary nature of PBE to teaching and learning including ways to assess student learning. Similarly, a study carried out in India by Bhat (2016) states that training programs are required to expose teachers to new ideas and perspectives of PBE. The study highlighted that trainings and workshops give prominence in the teachers' adoption of new practices. The challenges such as lack of time and resource constraints correspond with previous findings from PBE programs (Koinis, 2016; Powers, 2004; New, 2016). Correspondingly, a study in Bhutan by Kinley and Griffin (2017) at Samtse College of Education reported that issues with time and resources were also a major concern while implementing PBE at the tertiary level of education. The weather condition was another factor that impedes outdoor activities in a PBE class as claimed by Miller and Twum (2017) and Koinis (2016).

The Ministry of Education and the Royal Education Council made significant efforts to better equip teachers to engage students in collaboration with Teton Science Schools to integrate place-based education into our curriculum since 2008. From 2008 to 2021, over 500 teachers have been trained on PBE through a 5-day workshop. Moreover, the school leaders were trained to facilitate the use of PBE as a whole-school approach (REC, 2019). Further, to ensure that PBE is sustainable in the country, Trainer-of-Trainers (ToT) system was begun in 2013 among a group of teachers from all disciples who would then facilitate PBE professional development program at school levels (Griffin, 2019). However, the need for more professional programs on PBE may be attributed to the fact that after the 5-day training, there were no subsequent additional training programs provided for the teachers and there is a lack of monitoring mechanism to check the progress of implementation on a ground level. There seems to be a lack of sustained intervention to support the program for a long-term change. On the 
other hand, teachers for a long time have developed a strong fidelity to the national curriculum and deviating away from the established curriculum and syllabus to get acquainted new PBE pedagogical practices would require a considerable amount of time. Thus, transiting from old educational approach to a new approach like PBE would take some time especially for novice PBE educators to get a bigger picture.

The parallels between the place-based education approach and the Educating for GNH movement of Bhutan may provide a stable reference point for educators to increase their familiarity, and therefore adoption and implementation on PBE. Evidence from this study demonstrates how these similarities rest on both the structure and values of these two innovative educational approaches.

A set of philosophical pillars, revolving around the concept of sustainability, are central to both place-based education and educating for GNH. A critical understanding of "place" as a multidimensional concept rests at the foundation of a PBE approach. Though traditionally considered as a simple geographic location, PBE practitioners and scholars are tending towards a multidimensional understanding and holistic definition of place (Ardoin, 2006). The "Place Triangle" (or sometimes referred to as the sustainability triangle) is a convenient tool used to visualize one interpretation of the different place elements (Figure 3(a)). Viewed at the center of this triangle, place can be thought of encompassing collection of all of the ecologic, economic, and cultural elements related to the place. Importantly, these elements are interrelated in both their physical existence and the social interactions of communities in relation to them. As a foundation for place-based education, these place elements can offer a relevant and thematic starting point for the community-based inquiry projects documented at the MGVS.

GNH is rooted in the philosophies of Buddhist teachings, namely that individuals can gain merit through moral actions aimed to support all sentient beings of the collective world (Gyamtso et al., 2017; Sherab, 2013). To achieve these ends, the implementation of GNH oriented development is grounded in upon

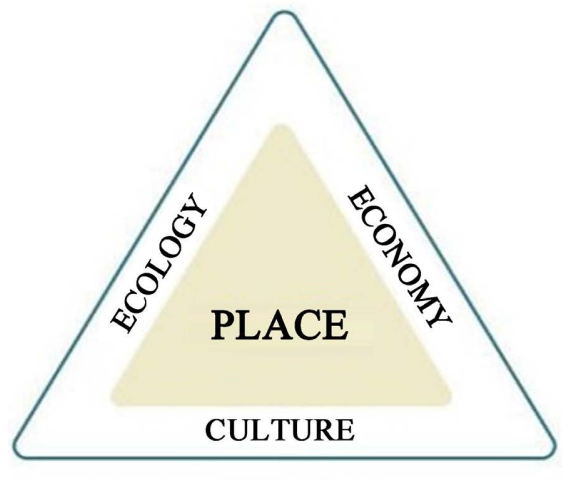

(a)

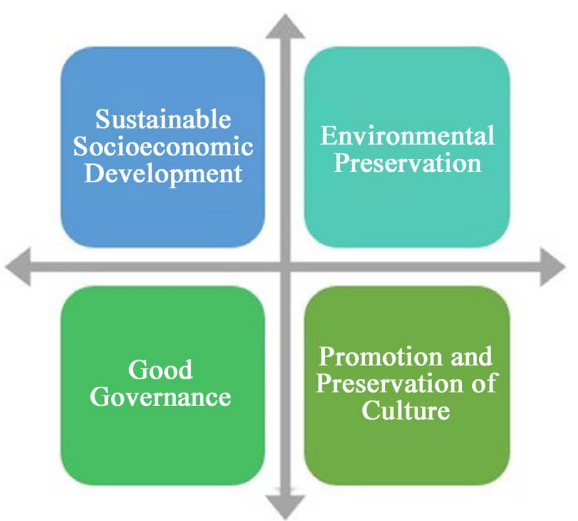

(b)

Figure 3. Graphical relationship of: (a) place triangle as used to frame PBE; and (b) the four pillars of GNH. 
four pillars (Figure 3(b)): 1). Sustainable and equitable socio-economic development; 2) the preservation and promotion of culture; 3 ) preservation and sustainable use of the environment; 4) good governance (Tshomo, 2016). Sherab (2013), citing Thinley (2005), describes how the social, cultural, environmental and governance pillars are interdependent and complementary in creating and enabling conditions for GNH.

An educational approach that is based on exploring elements of the place triangle necessitates incorporation of the GNH principles into learning. The GNH Pillars (and subsequent domains) targeting environmental preservation, cultural promotion, and sustainable socio-economic development directly relate to each of the three triangle components. Furthermore, when the place triangle model is considered holistically, the pillar of good governance can serve as an interdependent practice linking the implementation and cultivation of each component. This shared interdependence of parts again highlights the congruence between the two philosophies.

The structure and application of PBE further enables student progress towards the values at the core of Educating for GNH: those in the domains of the head (cognitive), the heart (affective), the hand (psychomotor) and the home (social-community). The accumulation of qualities and values in "oneself" is deemed vital in order to understand the world. As the child progresses from one level school to another (primary, lower secondary, middle secondary and higher secondary), they graduate with certain qualities and values in the manner of concentric rings such as an individual, as a family, at the workplace, in a community and as a global citizen (MoE, 2013). The PBE principle Local to Global enables students to learn that place begins first with their understanding of themselves and their service in the locality and expand to classrooms, schools, communities, regions and the world with certain qualities, skills and values at each level (TSS, 2019). And this is what a green school aspires to produce a GNH graduate who "when such a graduate enters the larger society, he or she should be able to release much goodwill and positive energy and make the society and the world a better place to live in" (Powdyel, 2014: p. 4). When considering place, the parallelism between the place triangle of PBE and the four pillars of GNH firmly indicate that place-based education would enable the infusion of GNH values in teaching.

\section{Conclusion}

This study showed that use of the local community for teaching and learning increased students' active engagement in the activities and subsequently enhanced their learning. With lessons guided by the PBE principles, students had the experience of hands-on learning in PBE classrooms. As supported by experiential learning theory, these practices were demonstrated to increase academic performance and intellectual capacity as a result of the hands-on learning experience. The study also found that a holistic approach of assessment was being 
practised to augment three domains of learning in students namely cognitive, affective and psychomotor. It was observed that a variety of assessment tools and techniques were in place to evaluate a child's growth in learning. The study also uncovered that while there are opportunities which pave easy path to execute $\mathrm{PBE}$, there are also several challenges that impede teachers from implementing PBE effectively in the classrooms. The main challenges teachers encountered in the application of PBE are lack of time and professional support. Finally, the study indicated that the PBE principles incorporated in lessons enable infusion of GNH values. It was observed that while all the eight dimensions of the Green School concept were manifested in the teaching and learning process, the three dimensions of Green School such as intellectual, academic, and social greenery were visibly prominent in the activities designed for the teaching and learning process. Therefore, it is an indicative that there is a strong synergy between PBE and GNH.

Informed by the data analyses, multiple recommendations can be made for other educators and institutions seeking to incorporate PBE into their educational approach. One consistent reflection of the teachers interviewed in this study was to have more sustained professional support while applying this approach in classrooms. A single opportunity of only one 5-day five-workshop was limited in its impact to furnish them with skills and content. Therefore, steady interventions are likely required to assist teachers in successfully implementing this approach. The practices of PBE of the research site could potentially be enhanced with the teachers of other schools by initiating School Based In-service Programs (SBIP). Under such a programme, participant teachers could build a stronger understanding of how PBE is being integrated extensively in a PBE model school.

Using well defined structures for PBE implementation is an additional recommendation emerging from the findings of this study. While place-based education can take on many forms and shapes dependent upon local context, utilization of over-arching educational principles can provide a grounding framework upon which practice and implementation of PBE can be based. In this study, the use of the local community as a classroom was one principle that emerged as an effective approach for creating transformative learning experiences. Engaging students with the people, places, and practices of the local community provided relevant and enriching experiences for applied learning. Furthermore, inquiry-based and learner-centered approaches used to structure these community investigations offered a framework in both action and outcome. Evidence of student learning from document analysis demonstrates how such critical inquiry investigations targeted both academic and socio-emotional outcomes within this student centric framework. To expand this recommendation into other contexts, educators are encouraged to look towards published frameworks for place-based education. While the six PBE principles reviewed within this work offer a reliable starting point (Vander Ark et al., 2020), additional frameworks developed for specific contexts and goals also offer valuable guidance. Examples including 
place-based approaches for urban environments (Russell-Ciardi, 2006) and those which target mindful-practices of place-based education (Deringer, 2017) offer such targeted approaches. Regardless of which principles are implemented, however, an emphasis on engaging local context remains imperative to successful PBE implementation. This study demonstrates how cultural context provides a foundation for PBE, and could be replicated at additional sites.

Building connections to locally rooted opportunities, challenges, and ways of thinking emerges as a final recommendation for PBE practice. For Bhutan, this natural congruency between Educating for GNH (and the Green School Domains) served as a relatable focal point for the alignment with place-based education. The PBE applications at this case study site were likely able to succeed in part due to their relevance towards the established trajectories of educational reform within the country. As a flexible educational model, this place-based practice focuses on teaching from a local to global approach. Such methods allow for not simply adopting foreign models, but adapting them to local contexts. Identifying similar developmental/cultural philosophies and tailoring place-based approaches to those systems could enable PBE to happen in other locations. Building such culturally relevant approaches would be but mutually supportive for strong place-based practices.

\section{Conflicts of Interest}

The authors declare no conflicts of interest regarding the publication of this paper.

\section{References}

Akbas, Y., \& Cakmak, S. (2019). The Effect of Place-Based Education Integrated Project Studies on Students' Problem-Solving and Social Skills. Asian Journal of Education and Training, 5, 183-192. https://doi.org/10.20448/journal.522.2019.51.183.192

Ardoin, N. M. (2006). Toward an Interdisciplinary Understanding of Place: Lessons for Environmental Education (P. 15).

Barnett, S. A. (2009). Place-Based Education and Teaching about Marin County Birds. Master's Thesis, Dominican University of California. https://files.eric.ed.gov/fulltext/ED504902.pdf

Bartholomaeus, P. (2006). Some Rural Examples of Place-Based Education. International Education Journal, 7, 480-489. https://files.eric.ed.gov/fulltext/EJ854303.pdf

Bhat, D. R. (2016). Adoption of Place-Based Learning in a Rural Primary Government School in India. Master's Thesis, Linköping University. http://www.diva-portal.org/smash/get/diva2:941354/FULLTEXT02.pdf

Bhutan Council for School Examinations and Assessment (2019). Education in Bhutan: Findings from Bhutan's Experience in PISA for Development. Bhutan Council for School Examinations and Assessment.

Bowen, G. (2009). Document Analysis as a Qualitative Research Method. Qualitative Research Journal, 9, 27-40. https://doi.org/10.3316/QRJ0902027

Creswell, J. W. (2009). Research Design: Qaulitative, Quantitative and Mixed Approaches (3rd ed.). SAGE Publications. 
Creswell, J. W. (2014). Research Design: Qaulitative, Quantitative and Mixed Approaches (4th ed.). SAGE Publications.

Creswell, J. W., \& Poth, C. N. (2016). Qualitative Inquiry and Research Design: Choosing among Five Approaches. Sage Publications.

Dani, D. (2019). A Community and Place-Based Approach to Middle Childhood Science Teacher Education. Middle School Journal, 50, 45-52. https://doi.org/10.1080/00940771.2019.1576581

Denman, B. D., \& Namgyel, S. (2008). Convergence of Monastic and Modern Education in Bhutan? International Review of Education, 54, 475-491. https://doi.org/10.1007/s11159-008-9085-0

Deringer, S. A. (2017). Mindful Place-Based Education: Mapping the Literature. Journal of Experiential Education, 40, 333-348. https://doi.org/10.1177/1053825917716694

Dolkar, T. (1995). Examination of the Bhutanese Secondary Social Studies Curriculum. Unpublished Master of Education Dissertation, University of New Brunswick.

Education Division (1989). Second Quarterly Policy, Guidelines and Instructions. Ministry of Education.

Gibbs, G. R. (2007). Qualitative Research Kit: Analyzing Qualitative Data. Sage. https://doi.org/10.4135/9781849208574

Gillis, A., \& Jackson, W. (2002). Research Methods for Nurses: Methods and Interpretation. Davis Company.

Goodlad, K., \& Leonard, A. E. (2018). Place-Based Learning across the Disciplines: A Living Laboratory Approach to. A Journal of Scholarly Teaching, 13, 150-164. https://doi.org/10.46504/14201808go

Griffin, E. (2019, June 6). From the Tetons to the Himalayas: An Evolving Place-Based Partnership in Bhutan.

https://www.tetonscience.org/from-the-tetons-to-the-himalayas-an-evolving-place-bas ed-partnership-in-bhutan

Gyamtso, D. C. (2013). An Inquiry into the Nature of Teaching and Learning at the Royal University of Bhutan. University of New England.

Gyamtso, D. C., \& Maxwell, T. W. (2012). Present Practices and Background to Teaching and Learning at the Royal University of Bhutan (RUB): A Pilot Study. International Journal of Teaching and Learning in Higher Education, 24, 65-75.

Gyamtso, D. C., Sherab, K., \& Maxwell, T. W. (2017). Teacher Learning in Changing Professional Contexts: Bhutanese Teacher Educators and the Educating for GNH Initiative. Cogent Education, 4, Article ID: 1384637.

https://doi.org/10.1080/2331186X.2017.1384637

Hayward, K., \& Colman, R. (2010). Educating for GNH. GPI Atlantic. http://www.gpiatlantic.org/pdf/educatingforgnh/educating for gnh proceedings.pdf

James, J. K., \& Williams, T. (2017). School-Based Experiential Outdoor Education: A Neglected Necessity. Journal of Experiential Education, 40, 58-71. https://doi.org/10.1177/1053825916676190

Kinley, \& Griffin, E. (2017). Place-Based Education in Action: Project Documentation at SCE. KMT Press.

Koinis, N. J. (2016). An Evaluation of the Impacts of the Teton Science Schools PlaceBased Education. Master's Thesis, University of Wyoming. https://mountainscholar.org/bitstream/handle/20.500.11919/1848/STUW SMTC 2016 Koinis Nicholas.pdf? sequence $=1$ \&isAllowed $=y$ 
Miller, D., \& Twum, S. (2017). The Experiences of Selected Teachers in Implementing Place-Based Education. Education, 23, 92-108. https://doi.org/10.37119/ojs2017.v23i1.282

Ministry of Education (MoE) (2012). 30th Education Policy Guidelines and Instructions. Ministry of Education.

Ministry of Education (MoE) (2013). Educating for Gross National Happiness: A Training Manual. Ministry of Education.

Ministry of Education (MoE) (2019). iSherig-2 Education ICT Master Plan 2019-2023. Ministry of Education.

Nespor, J. (2008). Education and Place: A Review Essay. Education Theory, 58, 475-489. https://doi.org/10.1111/j.1741-5446.2008.00301.x

New, K. C. (2016). Bringing the Classroom Outdoors: An Analysis of Toronto Educator Perceptions and Challenges. Master's Thesis, University of Toronto.

Opie, C. (2004). Doing Educational Research. Sage.

Phuntsho, K. (2000). On the Two Ways of Learning in Bhutan. Journal of Bhutan Studies, 2, 96-126.

Planning Commission (1999). Bhutan 2020: A Vision for Peace, Prosperity, and Happiness (Part $1 \& 2$ ).

Powdyel, T. S. (2014). My Green School. Kuensel Corporation Limited.

Powers, A. L. (2004). An Evaluation of Four Place-Based Education Programs. The Journal of Environmental Education, 35, 17-32. https://doi.org/10.3200/JOEE.35.4.17-32

Resor, C. W. (2010). Place-Based Education: What Is Its Place in the Social Studies Classroom? The Social Studies, 101, 185-188. https://doi.org/10.1080/00377990903493853

Rinzin, Y. C. (2017, June 18). Ministry Launches English for Effective Communication. Kuensel. https://kuenselonline.com/ministry-launches-english-for-effective-communication

Royal Education Council (REC) (2019). Annual Report 2019. Royal Education Council.

Russell-Ciardi, M. (2006). Place-Based Education in an Urban Environment. Museum International, 58, 71-77. https://doi.org/10.1111/j.1468-0033.2006.00570.x

Semken, S. (2005). Sense of Place and Place-Based Introductory Geoscience Teaching for American Indian and Alaska Native Undergraduates. Journal of Geoscience Education, 53, 149-157. https://doi.org/10.5408/1089-9995-53.2.149

Semken, S., \& Brandt, E. (2010). Implications of Sense of Place and Place-Based Education for Ecological Integrity and Cultural Sustainability in Contested Places. In D. Tippins, M. Mueller, M. van Eijck, \& J. Adams (Eds.), Cultural Studies and Environmentalism: The Confluence of Ecojustice, Place-Based (Science) Education, and Indigenous Knowledge Systems (pp. 287-302). Springer. https://doi.org/10.1007/978-90-481-3929-3 24

Semken, S., \& Freeman, C. B. (2008). Sense of Place in the Practice and Assessment of Place-Based Science Teaching. Science Education, 92, 1042-1057. https://doi.org/10.1002/sce.20279

Shannon, D. (2017). Teaching on the Farm: Farm as Place in the Sociology of Food and Sustainability. In Interdisciplinary Approaches to Pedagogy and Place-Based Education (pp. 11-22). Palgrave Macmillan. https://doi.org/10.1007/978-3-319-50621-0 2

Sherab, K. (2013). Gross National Happiness Education in Bhutanese Schools: Understanding the Experiences and Efficacy Beliefs of Principals and Teachers. University of New England. 
Smith, G. A. (2002). Place-Based Education: Learning to Be Where We Are. Phi Delta Kappan, 83, 584-594. https://doi.org/10.1177/003172170208300806

Smith, G. A. (2017). Place-Based Education. In Oxford Research Encyclopedia of Education. Oxford University Press. https://doi.org/10.1093/acrefore/9780190264093.013.95

Sobel, D. (2004). Place-Based Education: Connecting Classrooms and Communities. Orion Society.

Teton Science Schools (2017, February 22). TSS at 50 Years: Our "Why”. News. https://www.tetonscience.org/tss-at-50-years-our-why

Teton Science Schools (n.d.). Community as Classroom. https://www.tetonscience.org/programs/community-as-classroom

Thapa, A., Cohen, J., Guffey, S., \& Higgins-D’Alessandro, A. (2013). A Review of School Climate Research. Review of Educational Research, 83, 357-385. https://doi.org/10.3102/0034654313483907

The Bhutanese (2015, January 03). PM Launches the Education Blueprint 2014-2024. The Bhutanese. https://thebhutanese.bt/pm-launches-the-education-blueprint-2014-2024

Thinley, J. Y. (2005). What Is Gross National Happiness? 2nd International Conference on Gross National Happiness, Nova Scotia, 20-24 June 2005. http://www.bhutanstudies.org.bt

Tinder, C. (2018). The Impacts of Place Based Education in a Middle School Science Classroom. Master's Thesis, Montana State University. https://docplayer.net/140900713-The-impacts-of-place-based-education-in-a-middle-s chool-science-classroom-cathleen-tinder.html

Tshomo, P. (2016). Conditions of Happiness: Bhutan's Educating for Gross National Happiness Initiative and the Capability Approach. In M. J. Schuelka, \& T. W. Maxwell (Eds.), Education in Bhutan: Culture, Schooling, and Gross National Happiness (pp. 139-152). Springer. https://doi.org/10.1007/978-981-10-1649-3 9

TSS Teton Science Schools (2019, September 19). Getting Started with Place-Based Education, Step-by-Step. Place Network.

https://www.tetonscience.org/getting-started-with-place-based-education-step-by-step

Vander Ark, T., Liebtag, E., \& McClennen, N. (2020). The Power of Place: Authentic Learning through Place-Based Education. ASCD.

Wangchuk, J. (2019, April 24). School Curriculum Revised and Rationalised. Kuensel. https://kuenselonline.com/school-curriculum-revised-and-rationalised

Wangdi, T. (2016, July 17). Teachers Introduced to Transformative Pedagogy. Kuensel. https://kuenselonline.com/teachers-introduced-to-transformative-pedagogy

Wangmo, T., \& Valk, J. (2012). Under the Influence of Buddhism: The Psychological WellBeing Indicators of GNH. Journal of Bhutan Studies, 26, 53-81.

Woodhouse, J. L., \& Knapp, C. E. (2000). Place-Based Curriculum and Instruction: Outdoor and Environmental Education Approaches (pp. 1-8).

Zangmo, R. (2019, May 4). A New Standard to Measure Teachers' Competencies. Kuensel. https://kuenselonline.com/a-new-standard-to-measure-teachers-competencies 